GLOSSARY

\title{
Economics, demography, and epidemiology: an interdisciplinary glossary
}

\section{J A Tapia Granados}

\section{This glossary focuses on the "borderland" between demography, economic history, economic theory, and epidemiology}

Correspondence to:

J A Tapia Granados, The University of Michigan, Institute of Labor and Industrial Relations and School of Social Work, 1111 East Catherine Street, Ann Arbor, Michigan 48109-2054 USA; jatapia@umich.edu
When different fields of inquiry have been separately cultivated for a while, the borderland between them often provide fertile ground for new investigations. Allyn A Young, 1924

r $\mathrm{t}$ is a basic tenet of epidemiology that the conditions in which people live and work are important predictors of health outcomes, including the incidence and timing of specific disorders, injuries, disabilities, and death. Today epidemiology, demography, and economics are distinct fields with few overlapping areas, but the three disciplines once had common roots-in political arithmetic, political economy and such authors as William Petty, John Graunt, Thomas Malthus, and Frederick Engels. From its beginnings in the works of Johann Peter Frank, Louis Villermé, and Rudolph Virchow, the interactions of living and working conditions with health, disease, and mortality issues were a primary concern in the field of public health. During the 20th century epidemiological research has primarily focused on particular effects of the natural, social, and economic context (nutrition, income, education, social class, occupational exposures and behaviours, atmospheric pollutants, etc) on health, risk of disease, and mortality. Today there is a growing recognition of the importance of macroeconomic influences on health.

The focus of this glossary is the "borderland" between the fields of demography, economic history, economic theory, and epidemiology. The terms defined are drawn from publications that focus on the influence of the economy as a whole on health and mortality - or vice versa. However, despite their significance for epidemiology and health policy, many economic terms like "GDP", "economic growth", or "sustainable development" are not included because they are beyond the scope of this glossary.

Though epidemiologists often diverge on theoretical approaches and methodological nuances, there are few or no disagreements about basic epidemiological facts, methods and theories. No epidemiologist today defends the miasmatic
J Epidemiol Community Health 2003;57:929-935

theory or the causation of mental illness by the influence of the moon. Demography, which originally arose from a Malthusian background with strong emphasis on theories and mathematical models, often taken from economics, has recently developed into a largely empirical discipline, where checking the data can quite straightforwardly solve discrepancies. In economics however the situation is quite different, because not only the approaches but also the answers to basic problems depend on the theoretical orientation. For this reason this glossary also includes entries referring to the major currents of economic thought-neoclassical, Keynesian, Marxian, and ecological. Of course, even that these and not others are the main currents of economic thought would itself be matter of dispute among economists. In entries corresponding to economic concepts references are general and specialised works are not cited.

Terms appearing in SMALL CAPITALS are defined in other entries of the glossary.

\section{ACYCLICAL EFFECTS}

See BUSINESS CYCLE

\section{BOSERUPIAN PARADIGM}

According to the agricultural economist Esther Boserup, historically, high population density often led to the adoption of technical innovations and subsequent higher productivity in agriculture. ${ }^{1}$ In economic history or agricultural economics the term Boserupian is applied to effects or processes referring to a rise in productivity due to technical progress stimulated by population increase. McKeown ${ }^{2}$ criticised the Boserupian paradigm because the role it attributes to population induced technological change in the determination of food availability leaves population size itself as an undetermined variable, so that the change in population density is supposedly attributable to fortuitous causes such as infectious diseases.

\section{BRENNER'S HYPOTHESIS}

Since the 1970s, Harvey Brenner ${ }^{3-5}$ has maintained that recessions have an impact on population health, increasing both mortality (general mortality, cause specific mortality attributable to cardiovascular disease, infant mortality, etc) and morbidity (as measured for instance by the incidence of alcoholism, hospitalisations in mental institutions, etc). A number of authors $^{6-10}$ have criticised Brenner's contributions. Critiques have included the limitations of analysis based on time series of only a few 
decades-with very low statistical power-the controversial methods to detrend the series, and the contentious use of lags. Indeed, Brenner has never been very clear in stating the relation between the BUSINESS CYCLE and mortality. He referred to rising unemployment as leading to an increase in mortality, but he also mentioned "peak lags between unemployment and mortality rates[that] are two to three years in many industrialized countries" and also "adverse effects of rapid economic growth on mortality." ${ }^{4}$ As "on average, economic cycles tend to be $4-5$ years in length" and as there is a "classic 2- to 3-year lag in mortality after the peak in the unemployment rate (...) the zero-lag relationship between unemployment and mortality rates is actually inverse". ${ }^{5}$ This means, briefly, that mortality increases when unemployment decreases-that is, that mortality is PROCYCLICAL, which Brenner has never explicitly accepted. Indeed he has also asserted that economic recession "as measured by the unemployment rate, and/or by the business failure rate $(\ldots)$ is positively related to mortality over $0-10$ and 1-7 years, respectively". ${ }^{5}$ It is not clear what is the appropriate lag length to be considered and how a fixed-lag effect of unemployment overlapped on a non-periodical business cycle of roughly four to five years would consistently produce mortality peaks coinciding with economic booms, and mortality troughs coinciding with recessions.

Though Brenner's model of the relation between business cycles and mortality has been widely criticised, it has been around for the past 30 years and it is still cited, usually as evidence to support the need for expansionary economic policies. (See also BUSINESS CYCLES, EYER'S STRESS MODEL, and UNEMPLOYMENT.)

\section{BUSINESS CYCLES}

Since the early industrial revolution it has been observed that market economies show a succession of periods of upturn and downturn of business activity that have been called business cycles (industrial cycles and trade cycles are synonymous terms). The phase of increasing or accelerating economic activity of these "cycles" has been called "boom", "expansion" or "prosperity", while the phase of decreasing, contracting or slowing business has usually been referred to as "slump", "downturn" or "recession" when mild in intensity, "economic crisis" or "depression" if the deceleration of the economy is significant. ${ }^{11-13}$ Because of the irregularity of successive phases of expansion and contraction of the economy, the term "business cycle" has been much criticised and often replaced by "business fluctuation" or "economic fluctuation." Still business cycle has continued to be used and is the standard term in economic literature. ${ }^{14}$ After the second world war, it was believed that Keynesian theory would provide the appropriate tools necessary to minimise these fluctuations. But strong business fluctuations re-emerged in the 1970s and economic turbulence has been frequent in recent decades throughout the world.

\section{BUSINESS CYCLE INDICATORS}

Variables used to characterise the phases of the business cycle. Variables that fluctuate directly with the economy increasing when business expands (decreasing when the economy contracts) are called procyclical indicators (for example, growth rate of GDP, indices of industrial production, employment volume and rate, wages). Those in inverse relationship with the economy, increasing when the economy contracts, are called countercyclical-or rarely, anticyclical (for example, business failure rate, unemployment). Variables that do not correlate with business fluctuations are called acyclical. ${ }^{11-15}$

\section{BUSINESS FLUCTUATIONS}

See BUSINESS CYCLES

\section{COHORT SIZE HYPOTHESIS}

See EASTERLIN HYPOTHESIS

\section{COUNTERCYCLICAL EFFECTS OR VARIABLES}

See BUSINESS CYCLES

\section{DEMOGRAPHIC TRANSITION}

This term refers to the transformation of a society from high levels of fertility and mortality to low levels of both. The term usually implies that the drop in mortality occurs before the drop in fertility so that the transition includes a period of rapid population growth. The terms fertility transition and mortality transition refer respectively to the fertility and mortality components of the demographic transition. ${ }^{16}{ }^{17}$

In the original conceptualisation the demographic transition was considered to be a consequence of the transformation of society from a traditional to a modernised state through economic growth and industrialisation. ${ }^{16}$ Modern authors however tend to consider the causes of economic growth as distinct from those of mortality reduction, ${ }^{18}{ }^{19}$ with women's education and improvement of status playing an important part in the fall of fertility. The term epidemiological transition usually applies to the qualitative change in major causes of death associated with the demographic transition, with a large reduction in infectious diseases or "diseases of poverty", which are replaced as major causes of death by non-communicable diseases or "diseases of affluence". ${ }^{2}$

\section{DEMOGRAPHIC TRAP}

SEe POPULATION GROWTH

\section{DEMOGRAPHY}

SEe POPULATION GROWTH

\section{EASTERLIN HYPOTHESIS}

Other things being equal, the size of a birth cohort tends to have a negative effect on the social and economic fortunes of the members of that cohort. According to this demographic hypothesis, also known as the "cohort size hypothesis"stated by Richard Easterlin in $1980,{ }^{20}$ - a rise in birth rate would impact negatively on social and economic outcomes through "crowding mechanisms" operating in the family, the school and the labour market. Large cohorts would imply on average a larger number of siblings, less parental care, and school overcrowding, with reduced chances of educational attainment. The large cohort should subsequently be exposed to reduced opportunities in the job market, raised probability of unemployment, and the associated high risks of inadequacy, frustration, disproportionate consumption of alcohol, and higher crime and suicide rates. As the bad fortunes of a large cohort will reduce fertility when that cohort reaches reproductive age, the consequence will be a fall in cohort size and a new cohort with improved opportunities. The succession of cohorts alternating in size will tend to produce cycles in fertility also impacting a variety of social and economic outcomes. ${ }^{2021}$

The Easterlin hypothesis does not refer to what demographers and epidemiologists call cohort effect (or "generation effect"), ${ }^{22}$ which depends on specific exposures determined by a unique environment coinciding with the life span of the cohort. Conversely, the cohort size hypothesis has nothing to do with the particular exposures of a given cohort. Since its origin almost three decades ago empirical research on the Easterlin hypothesis has produced mixed results, with early research apparently disproving the 
hypothesis and recent studies producing some direct or indirect empirical support for it. ${ }^{23} 24$

\section{ECOLOGICAL ECONOMICS}

A recently developed field concerned with ecological issuesflows of matter and energy implied by the economic processes of an economy that is viewed as a subsystem of a larger finite global ecosystem-, that have been largely ignored by other schools of economic thought. ${ }^{25}$ Nicholas Georgesçu-Roegen may be considered its founder. ${ }^{26}$

\section{ECONOMIC CYCLES}

See BUSINESS CYCLES

\section{EPIDEMIOLOGICAL TRANSITION \\ See DEMOGRAPHIC TRANSITION}

\section{EYER'S STRESS MODEL}

In the late 1970s Joseph Eyer ${ }^{67-30}$ outlined a model in which stress occupies a central role as a mediator of influences generating a PROCYCLICAL oscillation of mortality. In Eyer's model, during periods of economic expansion increases in the consumption of toxic substances (alcohol and tobacco), surges in work pace, work time and overtime, and decreases in time and opportunity for social intercourse (with the consequent deterioration of social support) result in increases in levels of stress and diminished immunity, leading to acute cardiovascular disease and microepidemics of mild infectious diseases raising mortality among persons with chronic disease. Moreover, during business expansions high work pace and increasing business-related and recreational traffic raise the incidence of industrial injuries and traffic fatalities. Recent research has provided new evidence on the procyclical oscillation of mortality ${ }^{31-33}$ and a number of pathways $s^{34}$ linking business upturns to behavioural changes or exposure modifications that have or may have significant impacts on health as suggested by Eyer's model.

\section{FERTILITY TRANSITION}

\section{SEe DEMOGRAPHIC TRANSITION}

\section{HEALTH TRANSITION}

An ambiguous term that has been applied to (1) the escalation in life expectancy associated with the MORTALITY TRANSITION ${ }^{36} ;(2)$ the role of cultural, social, and behavioural determinants of health in the MORTALITY TRANSITION ${ }^{37}$; $(3)$ the evolution of morbidity levels during the historical decline of mortality (also called morbidity transition). ${ }^{37}$

\section{INDUSTRIAL CYCLES}

\section{See BUSINESS CYCLES}

\section{KEYNESIAN ECONOMICS}

System of economic ideas of John Maynard Keynes (18831946). In the 1930s, when unemployment was massive throughout the world, Keynes rejected the principle of classical economics that market economies naturally tend to equilibrium. He claimed that in capitalism there is a persistent tendency to insufficient solvent demand for the economic output, which results in overproduction and unemployment. According to Keynes, economic depressions can and must be resolved by active governmental interventions in the economy. In the 1950s Keynes's ideas were combined with those of the old classical school in Samuelson's "neoclassical synthesis", but the synthesis did not survive to recent decades, given that most economists have for the most part rejected or ignored Keynes's basic message - the need of government stimulation and regulation of the economy to avoid slumps. Today, Keynesian economics or Keynesianism refers historically to the ideas of Lord Keynes, or to a variety of present economic orientations, from the neo-Keynesian and new Keynesian, very close to the neoclassical school, to the post-Keynesian, still backing strong regulations and active economic interventions of governments. ${ }^{38-40}$

\section{MACROECONOMICS AND MICROECONOMICS}

Macroeconomics, initiated by the Keynesian school, refers to the analysis of the economy as a whole, looking at aggregate variables such as national output (measured by gross domestic or gross national product), national or regional unemployment, inflation, etc). Microeconomics deals with individual economic "agents", of which firms and consumers are the key ones in neoclasical economics. In contrast, Marxian theorists focus on labour-workers subjected to wage labour - and capital-business owners receiving profits. As macroeconomic conditions refer to the aggregate state of the economy, BUSINESS CYCLES can be conceptualised as recurring and roughly cyclical changes in macroeconomic conditions.

\section{MALTHUSIANISM}

In An Essay on the Principle of Population as it affects the future improvement of Society, with remarks on the Speculations of Mr. Godwin, M. Condorcet, and other writers, Thomas Malthus (17661834) upheld the idea that resource scarcity was the limiting factor arresting population growth. In so doing, he argued strongly against thinkers claiming that the human lot could be improved. Both Godwin and Condorcet had rejected Adam Smith's idea that individual selfishness led to general good and proposed that society could be improved by abolishing private property..$^{40}$ Speculating in his essay on why a rapid increase of the human species had not occurred, Malthus answered that "a foresight of the difficulties attending the rearing of family acts as a preventive check, and the actual distresses of some of the lower classes, by which they are disabled from giving the proper food and attention to their children, act as a positive check to the natural increase of population." ${ }^{\prime 41}$ The positive check resulted basically in early death because of hunger and epidemics. The preventive check would make people delay marriage or never marry at all, so reducing fertility and population growth. Although at the end of his life Malthus emphasised that in modern Europe "the principal check which at present keeps the population down to the level of the actual means of subsistence is the prudential restraint on marriage," he had previously stated that this preventive check would come into play very slowly, therefore implying that high mortality due to scarcity would be the regulating mechanism balancing human needs with natural resources in most periods of history. Any improvement in living conditions in the short term would generate population growth and "overpopulation", eventually checked by the subsequent increases in death rates because of overuse of resources. ${ }^{40} 42$

In the two centuries after Malthus food output grew faster than population in most countries. Present famines are usually considered the consequence of lack of purchasing power of poor people, not lack of food availability. However, among authors in different fields ${ }^{43}{ }^{44}$ the view is common that the rapid increase of human populations from the 18th century resulted largely from improved nutrition, and that in the 20th century, for the first time, "numbers and resources were in reasonable balance, so that the Malthusian adjustment through high mortality no longer operated" ${ }^{45}$ Today the effects of worldwide industrialisation, coupled with enormous 
population growth in the last century, have raised the possibility of severe impacts of human activity on nature, such as significant depletion of natural resources and global warming that could easily trigger "positive checks". ${ }^{44}$ Georgesçu-Roegen, often considered a founder of ecological economics, once said that Malthus had not been "Malthusian enough" ${ }^{46}$

\section{MARXIAN THEORY}

In the system of historical economic, and social ideas of Karl Marx (1818-1883), capitalism, like slavery or feudalism, is a transient stage in history. According to Marxian theory, the basic economic drives in capitalism-profit production and competition resulting in capital accumulation-make growing numbers of people redundant through the substitution of machines for human labour, and lead to increasing concentration and centralisation of capital with the continuous absorption of geographical regions and spheres of life into the realm of commodity production. In the Marxian view profits arise from surplus value created by workers in production, and since profits and wages, other things equal, are in inverse relation, an antagonism is established between those who live on wages (the working class) and those receiving profits (the capitalist class). Induced by the internal dynamics of capitalism, recurrent falls of profitability result in repeated depressions (crises) and escalating social and economic breakdown that will eventually lead to a classless societyor to barbarism. ${ }^{47}$ Marx viewed most economic theory of his time as apologetic for capitalism. Today, Marx's ideas are considered by neoclassical economists as foreign to economics and many authors of Marxian provenance classify themselves under the label of political economy.

\section{McKEOWN'S NUTRITIONAL DETERMINISM}

For Thomas McKeown the slow population growth before the 18th century was mainly attributable to food scarcity, and the rapid increase from that time was largely a result of improved nutrition. ${ }^{25}$ For McKeown the basic reason for the decrease in mortality due to infectious disease in Western Europe during the 18th and 19th centuries was the increase in host resistance to communicable disease, due to the improvements in immunity accompanying better nutrition. Though McKeown did not reject the role of hygiene and sanitary measures in the decrease in mortality, he considered them as playing a very minor part compared with nutrition. McKeown's nutritional theory has been criticised on the grounds that there is no evidence supporting an improvement in nutrition during the period of large mortality reductions while, on the other hand, there were many clear improvements in public health and urban sanitation that necessarily impacted on population health. ${ }^{19} 48$

\section{McNEIL'S LAW}

Historically, people living in large numbers in high density urban areas have had an epidemiological advantage over scattered peoples living in low density areas. While most people living in high density populations are immune to infectious diseases they were exposed to in childhood, most people in low density populations are susceptible to those diseases, so that explosive epidemics arise as soon as there is close contact among individuals from both sources. This law, first described by the historian William McNeil, ${ }^{49}$ may have played a substantial part in historical phenomena like the expansion of Middle East civilisations, the conquest of America by the Europeans after Columbus' arrival, and the explosive epidemics often triggered in isolated peoples by the arrival of European explorers. ${ }^{50}$

\section{MORBIDITY TRANSITION}

See HEALTH TRANSITION

\section{MORTALITY TRANSITION}

SEe DEMOGRAPHIC TRANSITION

\section{NEOCLASSICAL ECONOMICS}

Also known as marginalist or standard economics, and rooted in the ideas of Adam Smith (1723-1790) and the classical school, neoclassical economics is at the present the dominant school of economic thought. The models of neoclassical economics are based on methodological individualism (that views society as just an aggregate of individuals) and behavioural assumptions for firms (maximising profits) and consumers (maximising utility). Neoclassical economics posits that the market economy (referred to as "capitalism" by other schools) naturally tends to equilibrium, so that economic problems are attributable to influences from government interference or regulations, union activity, weather, or other factors disrupting the efficient functioning of markets. ${ }^{405152}$ Though Keynes rejected basic tenets of the classical school, in the 1950s Paul Samuelson combined the ideas of the old classical school with Keynes's theory in his "neoclassical synthesis", in which the need for some government influence to regulate the economy was accepted. The synthesis did not last long however and in recent decades the predominant orientation in neoclassical economics (monetarism) has all but totally discarded the Keynesian system. (See also KEYNESIAN ECONOMICS, STRUCTURAL ADJUSTMENT and UNEMPLOYMENT.)

\section{NEO-MALTHUSIANISM}

SEe POPULATION GROWTH

\section{NEOLIBERALISM}

See STRUCTURAL ADJUSTMENT

\section{NUTRITIONAL DETERMINISM}

See McKEOWN'S NUTRITIONAL DETERMINISM

\section{POPULATION GROWTH}

Population dynamics is a basic concern of demography. The age and sex structure of the total aggregate of people living at a particular time in a given area are the demographic variables impacting on population change, jointly determined by the rates of fertility, mortality and migration. The Malthusian view of population growth as the source of hunger and social misery was rejected by socialist thinkers, who upheld that the trend to produce "relative surplus population" - that is, unemployment-was a specific feature of capitalism..$^{53}$ Neo-Malthusianism, which claimed that population growth is a major cause of poverty, had a revival in some European countries in the last decades of the 19th century, and was adopted by conservative thinkers and some anarchists. However, in the early decades of the 20th century the decrease in fertility rates in many European countries and rising nationalism worried by the survival of particular nations or races raised pro-natalist movements and removed concerns about population growth. Neo-Malthusianism reemerged once again in the second half of the 20th century, when population growth was considered to produce a demographic trap of poverty and disease in former colonial regions, and authors like Paul $\mathrm{H}$ Ehrlich argued that increasing population size was the primary cause of environmental demise-the "population bomb". Negative population growth in advanced countries, fertility rates quickly decreasing around the world, and the surge in AIDS mortality in many countries where fertility is still comparatively high 
have shifted today's demographic concerns toward other areas like aging and ongoing mass. migrations. ${ }^{54}$

\section{POSITIVE CHECK \\ See MALTHUSIANISM}

\section{PREVENTIVE CHECK}

See MALTHUSIANISM

\section{PROCYCLICAL EFFECTS}

See BUSINESS CYCLE

\section{STRUCTURAL ADJUSTMENT}

In the decades after the second world war, under the influence of KEYNESIANISM, many African, Asian, and Latin American countries applied quotas, subsidies, and tariffs as part of import substitution policies to promote industrialisation and economic development, with governments actively financing infrastructure development and public services and intervening substantially in the economy. After several decades with mixed results in social progress, in the 1970s developing economies found themselves largely indebted, often with severe inflation and unemployment. At that time, when Keynesianism was being largely displaced in mainstream economics, and democratic leaders were often displaced by military regimes, structural adjustment (SA) programmes were put in place in most countries of Africa, Asia, and Latin America, promoted by the international financial institutions-World Bank and International Monetary Fund-now working under the paradigm of NEOCLASSICAL ECONOMICS and being the only providers of financing for the governments of the developing world. Basic aspects of SA programmes (also referred to as "the Washington consensus" or "neoliberalism") were currency devaluation, reduction of public spending, removal of subsidies, tariffs and trade barriers interfering with trade, deregulation, privatisation of public firms, and in general, a radical reduction of governmental involvement in the economy. The expected effect of SA was to eliminate the structural deficiencies of developing economies, resulting in a renewal of growth. ${ }^{55} 56$ The evaluation of the results reached by the application of SA policies is a matter of strong controversy, though there is consensus that the 1980s were a "lost decade" for development in Africa and Latin America. Mediocre or bad results in most indicators of social progress (poverty, unemployment, literacy...) are interpreted by those opposed to SA as implying a failure of these policies, while authors in the orbit of the World Bank and the IMF claim that policies were not properly implemented or interpret the data as showing some improvement that had not been possible without SA. Cuts in financing and delivery of public services and elimination of food subsidies associated with SA programmes often brought severe deterioration of healthcare services, education, and social welfare nets. ${ }^{57}$ However, evidence of an impact of SA programmes on specific health indicators in the countries of the developing world is not considered consistent even by authors opposed to SA policies. ${ }^{58} 59$ When the Soviet block collapsed in the early 1990s, SA programmes were quickly applied to Eastern European and ex-Soviet economies that had been for decades under centralised control of governments. The immediate results were sudden upsurges in poverty, unemployment, and social misery. Particularly in Russia and the other ex-Soviet republics, mortality escalated at unprecedented levels and fertility levels plummeted in the first half of the 1990s. ${ }^{60}$ Many social indicators in the countries of the developing world have stagnated or substantially deteriorated during the 1990s, but the institutions promoting SA continue defending these policies and claiming that they are the best way to reduce poverty.

\section{THOMAS' EFFECT}

In the 1920s Dorothy Thomas ${ }^{61}{ }^{62}$ showed that mortality, marriage rates, and birth rates oscillate procyclically-that is, rising when the economy expands and falling during recessions. Thomas was probably the first author clearly stating the PROCYCLICAL character of mortality-that is, the increase of mortality in times of economic upturn. This procyclical oscillation of death rates was called "Thomas' effect" by Joseph Eyer. ${ }^{6}$

\section{UNEMPLOYMENT}

Economists often divide unemployment into different categories such as frictional unemployment (that during the period between losing a job and getting a new one) or structural unemployment (attributable to long term changes in the economy, for instance railway workers unemployed when railroads are closed because of generalised road transportation). ${ }^{6364}$ In each category a larger or smaller proportion is considered to be made up of workers who could work and do consider themselves part of the labour force, but nevertheless choose, for whatever reason, to remain unemployed. This is voluntary unemployment while the rest is involuntary unemployment. The level of (un)employment in a country is considered by standard economics to reflect the interplay of labour supply (which is supposedly higher with higher wages) and labour demand (which is higher with lower wages), so that a high wage level will generate lower demand and larger supply of labour. When workers become jobless they will usually try to find work at their former wage level rather than below it. For these reasons it is often argued that unemployment benefits that are generous or easily available are likely to contribute to voluntary unemployment. If the income from benefits is more (or even slightly less) than the income that could be earned from employment, there is no incentive for someone to take a job when he or she can. These explanations provided by NEOCLASSICAL ECONOMICS are partially rejected by KEYNESIAN ECONOMICS and wholly criticised from the point of view of MARXIAN THEORY

Many epidemiological studies have focused on the effects of joblessness on health. While cross sectional ecological studies generally revealed higher mortality rates in countries and regions of high unemployment, the longitudinal ecological evidence is controversial. A number of studies through the 20th century ${ }^{616265-67}$ found a PROCYCLICAL oscillation of mortality - that is, mortality deviating up from trend during times of increased economic activity and low unemployment (only Hexter ${ }^{68}$ found a COUNTERCYCLICAL oscillation of mortality). Brenner also found mortality peaks coinciding with periods of rapid economic growth, but he explained this as a lagged effect on mortality of the previous recession (see BRENNER HYPOTHESIS). In the 1980s some studies $^{69-73}$ tend to support Brenner's interpretation, while others ${ }^{7-10}$ 74-77 tend to dismiss the evidence of any relationship between business cycles and mortality. Ruhm and Gerdtham ${ }^{31-33}$ have recently provided strong statistical evidence of a decline in age adjusted mortality both for all causes and for the major causes of death during recessions (in contrast, suicide mortality has been consistently found to escalate in recessions $^{31}{ }^{78}$ and is directly related to the level of unemployment). ${ }^{79} 80$

A large body of literature shows that in short follow ups of one or two years mortality in the unemployed is higher than in the employed. There has been much debate on whether this association is causal. Issues discussed in the literature $\mathrm{e}^{81-83}$ include bidirectional causation (with both ill health promoting loss of the job and joblessness inducing disease), mediating factors (unemployment causing reduction of income, and this in turn worsening health), and confounding (marginality or poor social adaptation causing both bad 
health and job loss). Interestingly, the relative risk of death of unemployed with respect to employed decreases during recessions, when unemployment surges. ${ }^{84-86}$ This suggests that the mortality differential between unemployed and employed during economic upturns may be driven by selection factors (or reverse causation). Alternatively, the health effects of unemployment may be modified by the context in which unemployment occurs. For example, the stress related consequences of unemployment may be less in a recession context when unemployment is widespread. ${ }^{87}$ Even assuming an increased risk of mortality in the unemployed, overall the relation between unemployment levels and mortality may be driven by the business cycle effects of working and consumption conditions of the nonunemployed population, always a large majority in comparison with unemployed.

\section{ACKNOWLEDGEMENTS}

The present version of this glossary has largely benefited from suggestions and criticisms of anonymous referees. Ana Diez Roux helped with editing and comments.

\section{REFERENCES}

1 Boserup E. The impact of scarcity and plenty on development. In: Rotberg RI, Rabb TK, eds. Hunger and history - the impact of changing food production and consumption patterns on society. Cambridge: Cambridge University Press, 1983.

2 McKeown T. The origins of human disease. Oxford: Basil Blackwell, 1988.

3 Brenner MH. Estimating the social costs of national economic policy: implications for mental and physical health, and criminal aggression. (Joint Economic Committee of Congress Paper no 5). Washington DC: US Government Printing Office, 1976.

4 Brenner MH. Mortality and economic instability-detailed analyses for Britain and comparative analyses for selected countries. Int J Health Services 1983; 13:563-619. (cited phrases on pages 565 and 617).

5 Brenner MH. Political economy and health. In: Amick III BC, Levine S, Tarlov AR, Walsh DC, eds. Society and health. New York: Oxford University Press, 1995. (cited phrase on page 237).

6 Eyer J. Prosperity as a cause of death. Int J Health Services 1977;7:125-50.

7 Kasl S. Mortality and the business cycle: some questions about research strategies when utilizing macro-social and ecological data. Am J Public Health 1979:69:784-9.

8 Winter J. Unemployment, nutrition and infant mortality in Britain, 1920-50. In: The working class in modern British history: essays in honour of Henry Pelling. Cambridge: Cambridge University Press, 1983.

9 Wagstaff A. Time series analysis of the relationship between unemployment and mortality: a survey of econometric critiques and replications of Brenner's studies. Soc Sci Med 1985;21:985-96.

10 Søgaard J. Econometric critique of the economic change model of mortality. Soc Sci Med 1992;34:947-57.

11 Zarnowitz V. Indicators. In: Eatwell J, Milgate M, Newman O, eds. The New Palgrave-a dictionary of economics. Vol 2. London: Macmillan, 1987:555-671 (paperback edn, 1998).

12 Medio A. Trade cycles. In: Eatwell J, Milgate M, Newman O, eds. The New Palgrave-a dictionary of economics. Vol 4. London: Macmillan, 1987:555-671 (paperback edn, 1998)

13 Sherman HJ, Kolk DX. Business cycles and forecasting. New York: HarperCollins, 1996.

14 Brandis R. Business cycles and business fluctuations. In: Gould J, Kolb WL, eds. A dictionary of the social sciences. New York: Unesco/Free PresMacmillan, 1964:62-3.

15 Gabisch G, Lorentz HW. Business cycle theory-a survey of methods and concepts, 2nd edn. Berlin: Springer-Verlag, 1989.

16 Coale A. Demographic transition. In: Eatwell J, Milgate M, Newman O, eds. The New Palgrave-a dictionary of economics. Vol 1. London: Macmillan, 1987:793-6 (paperback edn, 1998)

17 Last J, ed. Demographic transition. A dictionary of epidemiology, 4th edn. New York: Oxford University Press, 2001.

18 Easterlin R. Growth triumphant-the twenty-first century in historical perspective. Ann Arbor: University of Michigan Press, 1996.

19 Easterlin RA. How beneficent is the market? A look at the modern history of mortality. European Journal of Economic History 1999;3:257-94.

20 Easterlin RA. Birth and fortune: the impact of numbers on personal welfare. New York: Basic Books, 1980

21 Macunovich DJ. A conversation with Richard Easterlin. J Pop Econ 1997; 10:119-36.

22 Last J, ed. Generation effects. In: A dictionary of epidemiology. 4th edn. New York: Oxford University Press, 2001

23 Macunovich DJ. Fertility and the Easterlin hypothesis: "an assessment of the literature." J Pop Econ 1998;1 1:1-59.

24 Donohue JJ, Levitt SD. The impact of legalized abortion on crime. Q J Econ $2001 ; 116: 379-420$
25 Martínez Alier J. Ecological economics. In: Smelser NJ, Baltes PB, eds International encyclopedia of the social and behavioral sciences. New York: Elsevier, 2001:4016-23.

26 Beard RT, Lozada GA. Economics, entropy and the environment: the extraordinary economics of Nicholas Georgesçu-Roegen. Northampton, MA: Edward Elgar, 2000.

27 Eyer J. Does unemployment cause the death rate peak in each business cycle? Int J Health Services 1977:7:625-62.

28 Eyer J, Sterling P. Stress-related mortality and social organization. Rev Radical Polit Econ 1977;9:1-44.

29 Sterling $\mathbf{P}$, Eyer J. Biological basis of stress-related mortality. Soc Sci Med 1981;15E:3-42.

30 Eyer J. Capitalism, health, and illness. In: McKinlay JB, ed. Issues in the political economy of health care. New York: Tavistock, 1984.

31 Ruhm CJ. Are recessions good for your health? Q J Econ 2000;1 15:617-50.

32 Ruhm CJ. Economic expansions are unhealthy: evidence from microdato (NBER working paper no w8447). Cambridge, MA: National Bureau of Economic Research, 2001.

33 Gertham U-G, Ruhm C. Death rise in good economic times: evidence from the OECD (NBER working paper series no 9357). Cambridge, MA: National Bureau of Economic Research, 2002.

34 Sokejima S, Kagamimori S. Working hours as a risk factor for acute myocardial infarction in Japan: a case-control study. BMJ 1998;317:775-80.

35 Sparks K, Cooper C, Fried Y, et al. The effects of hours of work on health: a meta-analytic review. J Occup Organ Psychol 1997:70:391-408.

36 Riley JC. Rising life expectancy-a global history. Cambridge: Cambridge University Press, 2001.

37 Johansson SR. The health transition: the cultural inflation of morbidity during the decline of mortality. Health Transition Review 1991;1:39-65.

38 Bannock G, Baxter RE, Davis E. Keynesian economics; Keynes, John Maynard. Penguin dictionary of economics. 6th edn. London: Penguin, 1998:229-31, 232-3.

39 Eatwell J. Keynesianism. In: Eatwell J, Milgate M, Newman O, eds. The New Palgrave-a dictionary of economics. Vol 3. London: Macmillan, 1987:46-7 (paperback edn, 1998).

40 Routh GR. The origin of economic ideas. White Plains, NY: Sharpe, 1975.

41 Malthus TR. An essay on the principle of population. In: Flew AG, ed. London: Penguin, 1970 (original edn 1798).

42 Schofield $\mathbf{R}$. The impact of scarcity and plenty on population change in England, 1541-1871. In: Rotberg RI, Rabb TK, eds. Hunger and history-the impact of changing food production and comsumption patterns on society. Cambridge: Cambridge University Press, 1983:67-94.

43 Fogel R. The relevance of Malthus for the study of mortality today: long-run influences on health, mortality, labor force participation and population growth. In: Lindahl-Kiesling K, Landberg $\mathrm{H}$, eds. Population, economic growth, and the environment. New York: Oxford University Press, 1994.

44 Cairns J. Matters of life and death : perspectives on public health, molecular biology, cancer, and the prospects for the human race. Princeton: NJ, Princeton University Press, 1997; chapters 1 and 6.

45 McKeown T. Food, infection, and population. In: Rotberg RI, Rabb TK, eds. Hunger and history - the impact of changing food production and consumption patterns on society. Cambridge: Cambridge University Press, 1983:29-50.

46 Georgesçu-Roegen N. Comments on the papers by Daly and Stiglitz. In: Kerry Smith V, ed. Scarcity and growth reconsidered. Baltimore: Johns Hopkins University Press, 1979:96.

47 Korsch K. Karl Marx. London: Chapman and Hall, 1938

48 Szreter S. The importance of social intervention in Britain's mortality decline c. 1850-1914: a reinterpretation of the role of public health. Soc Hist Med 1988;1:1-37.

49 McNeil WH. Plagues and peoples. New York: Anchor Books, 1989

50 Crosby AW. Ecological imperialism-the biological expansion of Europe, 900-1900. Cambridge: Cambridge University Press, 1986.

51 Aspromourgos T. 'neoclassical'. In: Eatwell J, Milgate M, Newman O, eds. The New Palgrave-a dictionary of economics. Vol 3. London: Macmillan, 1987:625 (paperback edn, 1998).

52 McCarty M. The Nobel Laureates - How the world's greatest economic minds shaped modern thought. New York: McGraw-Hill, 2000; chapters 1-5.

53 Bottomore T, Himmelweit S. Population. In: Bottomore T, ed. A dictionary of Marxist thought. Cambridge, MA: Harvard University Press, 1983:378-80.

54 Hodgson D. Demography: twentieth-century history. In: Smelser NJ, Bates PB, eds. International encyclopedia of the social and behavioral sciences. New York: Elsevier, 2001:3493-8.

55 Barret C. Structural adjustment policies. In: O'Hara PA, ed. Encyclopedia of political economy. Vol 2. New York: Routledge, 1999:1115-18.

56 Schydlowsky DM, ed. Structural adjustment-retrospect and prospect. Westport, CO: Praeger, 1995.

57 Adepoyu A, ed. The impact of structural adjustment on the population of Africa. London: UNFPA/Heinemann, 1993.

58 Abbassi K. The World Bank and world health-under fire. BMJ 1999:318:1003-6

59 Wakkweya AM. Structural adjustment and health. BMJ 1995;311:71-3.

60 McKee DA. The health consequences of the collapse of the Soviet Union. In: Leon DA, Walt G, eds. Poverty, inequality and health: an international perspective. New York: Oxford University Press, 2001:17-38.

61 Ogburn WF, Thomas DS. The influence of the business cycle on certain social conditions. J Am Stat Assoc 1922;18:324-40.

62 Thomas DS. Social aspects of the business cycle. London: Routledge, 1925.

63 Bannock G, Barter RE, Davis E. Unemployment. In: Penguin dictionary of economics. 6th edn. London: Penguin, 1998. 
64 Hargreaves-Heap S. Unemployment. In: Eatwell J, Milgate M, Newman O, eds. The New Palgrave-a dictionary of economics. Vol 4. London: Macmillan, 1987:745-9 (paperback edn, 1998).

65 Huntington E. World-power and evolution. New Haven: Yale University Press, 1920 (reprint 1929): chapters II-IV

66 Higgs R. Cycles and trends of mortality in 18 large American cities, 18711900. Explorations in Economic History 1979;16:381-408.

67 Jin RL, Shah CP, Svovoda TJ. The impact of unemployment on health: a review of the evidence. Can Med Assoc J 1995; 153:529-40.

68 Hexter MB. Social consequences of business cycles. Boston: Hougton Mifflin, 1925.

69 Bunn AR. Ischaemic heart disease mortality and the business cycle in Australia. Am J Public Health 1979;69:772-81.

70 Bunn AR. I[schemic]H[eart]D[isease] mortality and the business cycle in Australia. [Letter]. Am J Public Health 1980;70:410-14.

71 Watkins S. Recession and health: a literature review. In: Wescott G Svensson P-G, Zölner HFK, eds. Health policy implications of unemployment. Coppenhagen: World Health Organisation Regional Office for Europe, 1985.

72 McAvinchey ID. Economic factors and mortality: some aspects of the Scottish case 1950-1978. Scottish Journal of Political Economy 1984;31:1-27.

73 Junankar PN. Unemployment and mortality in England and Wales: a preliminary analysis. Oxford Economic Papers 1991;43:305-20.

74 Goff BL. Health and the economy: exogenous versus choice variables. Kyklos 1980:43:437-84

75 Forbes JB, McGregor A. Unemployment and mortality in post-war Scotland $J$ Health Econ 1984;2:239-57.
76 LaPlante MP. Mortality and the business cycle. [PhD dissertation]. Stanford CA: Department of Sociology, Stanford University, 1985.

77 Kagan AR. Unemployment causes ill health: the wrong track. Soc Sci Med 1987;25:217-18.

78 Dooley D, Fielding J, Levi L. Health and unemployment. Annu Rev Public Health 1996;17:449-65.

79 Boor M. Relationship between unemployment rates and suicide rates in eight countries, 1962-1976. Psychol Rep 1980;47:1089-101.

80 Bollen KA. Temporal variation in mortality: a comparison of US suicides and motor vehicle fatalities 1972-1976. Demography 1983;20:45-59.

81 Stern J. The relationship between unemployment, morbidity and mortality in Britain. Pop Stud 1983;37:61-74.

82 Bartlet M. Unemployment and health selection. Lancet 1996;348:904-5.

83 Mathers CD, Schofield DJ. The health consequences of unemployment. Med J Austr 1998:168:178-82.

84 Valkonen T, Martikainen P. The association between unemployment and mortality: causation or selection? In: Lopez AD, Casell G, Valkonen T, eds. Adult mortality in developed countries: from description to explanation. Oxford: Clarendon Press, 1995:201-22.

85 Martikainen PT, Valkonen T. Excess mortality of unemployed men and women during a period of rapidly increasing unemployment. Lancet 1996;348:909-14.

86 Martikainen PT, Valkonen T. The effects of differential unemployment rate increases of occupation groups on changes in mortality. Am J Public Health 1998;88:1859-61

87 Blake Turner J. Economic context and the health effects of unemployment. J Health Soc Behav 1995;36:213-29.

\section{THE JECH GALLERY}

\section{Less medicine, more health: a memoir of Ivan Illich}

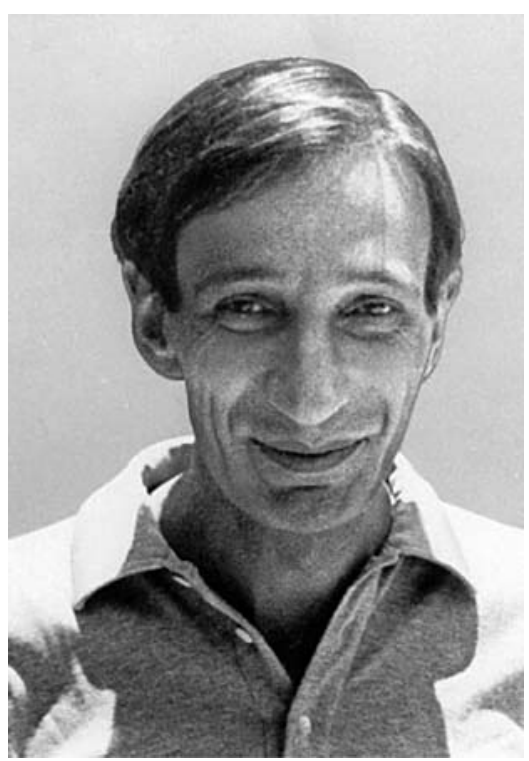

Photo credit Associated Press.
$\mathrm{C}$ ontemporary medicine is not comfortable with polymaths: it cannot easily handle visions that transcend its narrowly defined specialist boundaries. This is paradoxical given medicine's cultural imperialism - the ways in which it constantly crosses social boundaries and in which (as Marxists have it) it continually reproduces itself as it gobbles up more areas of our social lives (a current example being the invention of "female sexual dysfunction"'1).

Ivan Illich was well ahead of his time ${ }^{2}$ in identifying and classifying the health hazards of the "medicalisation of society". In the mid-1970s he used medicine as an example of his general thesis that industrialisation and bureaucracy were appropriating areas of life previously regarded as personal. In particular, he identified how drugs and other medical technologies remove personal responsibility for suffering and create dependence on health care, which itself has a wide range of hazardous slide effects. ${ }^{3}$

Perhaps it is clearer today that medicine's cultural imperialism is not itself a cultural product but is primarily a result of the profit motive. None the less, it is paradoxical that Illich's critique was at the time so unwelcome to the "health left". Navarro found it "unhistorical and unempirical", while for Berliner, Illich gave "additional ammunition to those who seek monopoly capital control of health providers and the health system". ${ }^{5}$ Notable among wide ranging characterisations of Illich's thesis were romantic idealism 6 and "vulgar Marxism". 7

Illich's dramatic and powerful language enhanced both his positive and negative impacts: "The medical establishment has become a major threat to health" "3; "...it now seems rational to flee pain rather than to face it" $^{\prime 2}$; "...irreparable damage accompanies industrial expansion in all sectors".2

His perspective was by no means a static one: 10 years after Medical Nemesis, Illich felt that "Today's major pathogen is, I suspect, the pursuit of a healthy body". ${ }^{8}$ And 20 years on, he saw society as viewing life in systems terms, and asked despairingly "...is there still an autonomous self capable of the act of dying?" compelling reason why one who practises medicine could not also be a friend..."

I met Illich briefly in 1978 when he visited Manchester and we corresponded for two years. In retrospect, his thesis of the disabling of society through the direct dominance of professionalism and industrialisation seems over-simplistic. Clearly it lacked a critique of capitalism-which is surely the driving force behind professional hegemony. It also gave insufficient credit to the achievements of medicine-as a diabetic with retinopathy, I'd certainly be dead or blind without insulin or the laser. But as a preacher of revolution in the politics of health, Illich had few equals.

Liverpool Public Health Observatory, Department of Public Health, University of Liverpool, Liverpool L69 3GB, UK; alexss@liverpool.ac.uk

\section{REFERENCES}

1 Moynihan R. The making of a disease: female sexual dysfunction. BMJ 2003;326:45-7

2 Illich I. Medical nemesis. Lancet 1974:i:918-21.

3 Illich I. Limits to medicine: medical nemesis - the expropriation of health. London: Marion Boyars, 1976.

4 Navarro V. Political power, the state, and their implications in medicine. Review of Radical Political Economics 1977;9:61-80.

5 Berliner HS. Emerging ideologies in medicine. Review of Radical Political Economics 1977:9:116-24.

6 Hart N. The sociology of health and medicine. Ormskisk, Lancashire: Causeway Press, 1985.

7 Fox RC. The medicalization and demedicalization of American society. In: Knowles JH, ed. Doing better and feeling worse: health in the United States. New York: WW Norton, 1977:9-22.

8 Illich I. Body history. Lancet 1986;ii:1325-7.

9 Illich I. Death undefeated. BMJ 1995;311:1652-3. 